\title{
Factors Associated with Aseptic Osteonecrosis in Hospital Settings in Yaounde, Cameroon
}

\author{
Madeleine Singwé-Ngandeu1,2, Amina Al-Maye Bit Younouss' ${ }^{1}$, Bernard Chetcha Chemeni' \\ Ibrahima Farikou1, Magloire Biwole Sida1, Paul Olivier Koki Ndombo \\ ${ }^{1}$ Faculty of Medicine and Biomedical Sciences, The University of Yaounde I, Yaounde, Cameroon \\ ${ }^{2}$ Rheumatology Unit, Yaounde Central Hospital, Yaounde, Cameroon \\ Email: ngandeum@yahoo.fr
}

Received 16 January 2015; accepted 4 February 2015; published 10 February 2015

Copyright @ 2015 by authors and Scientific Research Publishing Inc.

This work is licensed under the Creative Commons Attribution International License (CC BY). http://creativecommons.org/licenses/by/4.0/

(c) (7) Open Access

\section{Abstract}

Introduction: Osteonecrosis is the cellular death of the various components of bone. It mostly affects the femoral head, and its real incidence is unknown. Many causative factors may be involved in its genesis. In Sub-Saharan Africa, it affects mainly young patients and the $S$ and $C$ hemoglobinopathies are the most affected backgrounds. Objective: To determine factors associated with aseptic osteonecrosis of the femoral head in hospital settings in Yaounde, Cameroon. Methodology: It was a cross-sectional multicentric study on 29,474 files of black Cameroonian patients seen during consultation or admission, within a five-year period, carried at the Central Hospital, the National Center for Rehabilitation of Handicaped Persons and at the FROT Clinic in Yaounde, Cameroon. Files of patients with aseptic osteonecrosis of the femoral head ( 1 file $=1$ patient) were enrolled. The diagnosis was retained solely based on clinical and radiologic criteria. Magnetic resonance imaging, tomodencitometry and/or bone scintigraphy were also considered when available. Classification of lesions obeyed Ficat-Arlet criteria. Patients' files with little information and hip diseases other than aseptic osteonecrosis were excluded. Results: Fifty-one cases $(0.17 \%)$ of aseptic osteonecrosis were recruited; among them, there are 28 males (55\%) and 23 females $(45 \%)$. Their mean age was $38.9 \pm 16.4$ years (extremes: 7 and 78 years). Those aged 21 to 30 years represented $25.5 \%$ of cases. Pain and loss of function were present in all patients. The lesion occurred in the right hip in 22 cases $(41.1 \%)$, and left hip in 13 cases $(25.5 \%)$; 16 patients $(31.4 \%)$ had both hip affected. X-ray was performed for all patients. Radiologic lesions were at Stage IV in 2 cases (3.9\%), III for 44 cases $(86.3 \%)$, and II in 5 cases $(9.8 \%)$. Factors associated with aseptic osteonecrosis were observed in 29 patients and their frequencies were as follows: sickle cell disease: $n=12(25.3 \%)$; trauma: $n=10(19.6 \%)$; alcoholism: $n=3(5.9 \%)$; athletic practice: $n=3(5.9 \%)$; and 2 patients $(3.9 \%)$ were on treatment with steroid. HIV infection occurred in 2 cases (1.9\%); dyslipidemia, hyperuricemia and systemic lupus erythematosus were diagnosed in 1 case (1.9\%)

How to cite this paper: Singwé-Ngandeu, M., Younouss, A.A.-M.B., Chemeni, B.C., Farikou, I., Sida, M.B. and Ndombo, P.O.K. (2015) Factors Associated with Aseptic Osteonecrosis in Hospital Settings in Yaounde, Cameroon. Open Journal of Rheumatology and Autoimmune Diseases, 5, 12-16. http://dx.doi.org/10.4236/ojra.2015.51003 
each. Conclusion: The relative incidence of aseptic osteonecrosis of the femoral head in hospital settings in Yaounde is $\mathbf{0 . 1 7 \%}$ and mostly young adults are affected. Lesions are discovered at an advanced radiographic stage and sickle cell disease is the first associated factor.

\section{Keywords}

\section{Osteonecrosis, Sickle Cell Disease, Risk Factor, Femoral Head}

\section{Introduction}

Osteonecrosis is the death of the different cellular components of the bone [1]. Epiphysial osteonecrosis in adults is frequent and aseptic necrosis of the femoral head (AONFH) is the most common feature. In the United States of America, 15,000 to 30,000 new cases are diagnosed every year. In Europe, the incidence is probably the same [2].

In Africa and particularly Sub-Saharan Africa, osteonecrosis prevalence is still unknown. Nevertheless, this pathology is often described in association with sickle cell anemia [3]-[5] and infection by human immunodeficiency virus [6] [7]. Equatorial Africa has a prevalence of sickle cell anemia trait that varies between $10 \%$ and $40 \%$ [8], and HIV infection is endemic in this region [4]. The latter increases the risk of occurrence of aseptic osteonecrosis by 100 times when compared to a normal healthy general population [6]. Other factors like steroid treatment and alcoholism are also incriminated in the genesis of avascular bone necrosis [7] [9] [10].

Osteonecrosis is the principal osteo-articular complication of sickle cell anemia in Cameroon [11]. It accounts for $2.7 \%$ of osteoarticular problems during HIV/SIDA in Douala [12]. However, few or no study has investigated factors that favor aseptic osteonecrosis in our country. Our study was aimed at bridging this gap, in hospital settings in Yaounde, Cameroun.

\section{Methodology}

We carried out a cross sectional multicentric study, during a period of 5 years, from January 2006 to December 2010. It took place at the Central Hospital, National Center of Rehabilitation of Handicapped Person and FROT private orthopedic clinic in Yaounde, Cameroon. Patients were examined at outpatient consultations and/or on admission. Medical files from Cameroonian black patients suffering from aseptic osteonecrosis of femoral head were included in the study. File with little information and patient with hip disease other than aseptic osteonecrosis were excluded. Each patient received a standard hip radiography (face view and false profile view of Lequesne). Magnetic resonance, tomodensitometry and/or bone scintigraphy were considered if done. For each retained file, demographic (age, sex, profession), clinical and para-clinical details were collected. We considered as case of osteonecrosis, all patients presenting at least one clinical criterion (hip pain and/or functional impotence of a limb) plus one of the following radiographic criteria and/or scintigraphic, scanographic and magnetic resonance imaging features: Radiographic criteria considered were bone demineralization, loss of bone margins, sub-chondral clarity, necrotic bone dissection, coxarthrosis signs. As for scintigraphic criteria, they included hypo fixation at start, hyper fixation, or mostly a typical hypo fixation localized a line by a crescent hyper fixation; tomographic criteria: heterogenic aspects with juxtaposition of hypodense and hyper dense zones, or lately peripheral hypodensity with hyperdensity; diagnostic criteria on MRI were hypo signal margins, variable "sequestre”, and presence of fluid in the hip joint.

Was considered as aseptic, any osteonecrosis that occurred in a non-infectious context. Aseptic osteonecrosis lesions of femoral head were classified with respect to Ficat-Arlet classification criteria [13].

This study protocol received the approval from the institutional ethical committee of Faculty of Medicine and Biomedical Sciences of the University of Yaounde I.

\section{Results}

In a total of 29,474 files reviewed, 51 cases (0.17\%) of osteonecrosis were collected, among them 28 men (55\%) and 23 women (45\%). The sex ratio (M/W) was 1.2. Patients' average age was $38.9 \pm 16.4$ years (extremes 7 
and 78 years) and those aged between 21 and 30 years represented $25.5 \%$ of subjects. All patients presented with aseptic osteonecrosis of femoral head. Pain and impaired function were present in all patients upon diagnosis. Lesions were found in the right hip in 22 cases (41.1\%), or left hip in 13 cases (25.5\%); they were bilateral in 16 cases (31.4\%). Radiological lesions were of Stage III in 44 cases (86.3\%), Stage II for 5 cases (9.8\%) and at Stage IV in 2 cases (3.9\%). X-ray examination was the main method of diagnosis confirmation for the 51 patients. Only one patient had scanographic examination and bone scintigraphy. None of them had MRI.

Factors associated with aseptic osteonecrosis (Table 1 and Table 2) were found in 29 patients (56.86\%). Among them, six patients (11.9\%) presented with more than one factor (Table 3).

Table 1. Frequency of factors associated with AONFH.

\begin{tabular}{cc}
\hline Risk factors & Frequencies (\%) \\
\hline Sickle cell disease & $12(23.5)$ \\
Trauma & $10(19.6)$ \\
Alcoholism & $3(5.9)$ \\
Athletism & $3(5.9)$ \\
Steroids & $2(3.9)$ \\
HIV infection & $2(3.9)$ \\
Dyslipidemia & $1(1.9)$ \\
Hyperuricemia & $1(1.9)$ \\
Systemic lupus erythematosous & $1(1.9)$ \\
\hline
\end{tabular}

Table 2. Frequency of each factor per patient.

\begin{tabular}{cc}
\hline Risk factors & Frequencies (\%) \\
\hline Sickle cell disease & $9(17.6)$ \\
Trauma & $6(11.8)$ \\
Athletism & $3(5.9)$ \\
Alcoholism & $2(3.9)$ \\
HIV infection & $2(3.9)$ \\
Corticotherapy & $1(2)$ \\
\hline
\end{tabular}

Table 3. Association of more than one factor in the same patient.

\begin{tabular}{cc}
\hline Risk factors & Frequencies (\%) \\
\hline Sickle cell disease and trauma & $3(5.9)$ \\
Dyslipidemia and alcoholism & $1(2)$ \\
Hyperuricemia and trauma & $1(2)$ \\
$\begin{array}{c}\text { Systemic lupus erythematosus } \\
\text { and steroid treatment }\end{array}$ & $1(2)$ \\
Total & $6(11.9)$ \\
\hline
\end{tabular}




\section{Discussion}

The frequency of this disease was $0.17 \%$ in this study. It could have been under estimated, since our study was a retrospective including only symptomatic cases. Although this study took place in hospital settings which gathered most of the patients, some could have consulted not only in other sanitary institutions, but also the traditional healers. Despite the fact that there were insufficiencies in our technical scale (lake of magnetic resonance imaging and bone scintigraphy), aseptic osteonecrosis main location was the femoral head, and most of patients were rather young. Our results were close to those from Burkina Faso [7] and to data from western countries [14]. Men were more affected than women, as previously observed [15]. Among factors associated with osteonecrosis, sickle cell anemiahomozygote SS ranked high like in Burkina Faso [7]. Patient's young age, traumatic ischemia from vascular obstruction by micro-thrombosis formation with piled up sickled erythrocytes [16] and fibrinolysis impaired [17] could explain such lesions. However, the presence of sickle cell anemia trait should not influence the methods use in finding osteonecrosis risk factors. Trauma was reported as a risk factor associated with osteonecrosis of femoral head in 3 sicklers' in Togo [18], but in this study, trauma was rather a minor factor. In many studies, aseptic osteonecrosis of femoral head is a frequent complication of fracture femoral neck and hip luxation; the occurrence of osteonecrosis is explained by the rupture of the round ligament and affection of retinacula arteries [2] [7] [14] [15]. Unlike different studies, alcoholism, described to be the second major cause of osteonecrosis non associated to a trauma [10] [19], was less associated to osteonecrosis in this series. In Burkina Faso, alcoholism was more frequent in adult patients with aseptic osteonecrosis [7]. Athletics practice which appears as another factor associated with osteonecrosis in our study wasn't noted by previous authors. Repeated micro trauma cause by such practice, could explain this finding [20]. HIV infection was less observed in our patients, unlike Burkina Faso [7] and Caucasians subjects. Corticotherapy [19], described as being the first cause of aseptic osteonecrosis was observed in only 3.9\% of subjects. Osteonecrosis occurred in 5\% to $40 \%$ of patients on long termsteroid treatment [9]. The observed contrast is difficult to interpret. For most of patients in their study, steroid treatment was addressing an underlying disease, like systemic lupus erythematosus, that might have added to causing bone lesion [21]-[23]. However, corticotherapy is also incriminated in the genesis of aseptic osteonecrosis in SLE [15] [23]. SLE is uncommon in our context. In more than one-third of subjects, no factor was associated with osteonecrosis; Blum et al., reported the absence of risk factor frequency of $10 \%$ to $25 \%$ [2]. Having a detailed patient history is a prominent challenge here, where some clinical signs of co morbidities might have been left aside. Most of radiological lesions were at late. No early lesion was observed. Magnetic resonance and bone scintigraphy were not readily available for all patients, and they only have spotted such features [2]. Moreover, certain cases, with multifocal lesions might have been under diagnosed. Osteonecrosis, in our study affected the femoral head of all patients, mostly in the right hip, or on both femurs, contrasting with different studies results [1] [7] [22].

\section{Conclusion}

In conclusion, this study suggests that osteonecrosis remains scarce in our environment and occurs principally on the femoral head. Its diagnosis is often late, with radiographic lesions in later stages in most of the cases, and, sickle cell anemia is the main risk factor. Further study is required within the general population in Cameroon, in order to determine its real prevalence and risk factors in our environment.

\section{References}

[1] Hernigou, P. (2006) Ostéonécroses non traumatiques des épiphyses de l’adulte EMC. Elsevier SAS, Paris.

[2] Blum, A., Bressler, F., Deneuville, M., Pere, P., Chary-Valckenaere, I., Grignon, B. and Regent, D. (1996) Osteonécrosesépiphysaires de l'adulte. EMC 5 Elsevier, Paris, Radiodiagnostic-Neuroradiologie-Appareil Locomoteur, 16 p.

[3] Jeandel, P., Chouc, P.Y. and Laroche, R. (1991) Rhumatologie en Afrique noire, certitudes, perspectives et inconnues. Médecine d'Afrique Noire, 38, 53-61.

[4] Rufai Bologun, A., Obalum, D.C., Giwa, S.O., Adekoka-Cole, T.O., Chidiebere Ogo, N. and Enweluzo, G.O. (2010) Spectrum of Musculo-Skeletal Disorders in Sickle Cell Disease in Lagos, Nigeria. Journal of Orthopaedic Surgery and Research, 5, 2. http://dx.doi.org/10.1186/1749-799X-5-2

[5] Jean-Baptiste, G. and De Ceulaer, K. (2003) Actualités des manifestations rhumatologiques des hémoglobinopathies. Revue Du Rhumatisme, 70, 157-161. http://dx.doi.org/10.1016/S1169-8330(02)00036-4 
[6] Levasseur, R. (2008) Mechanisms of Osteonecrosis. Joint Bone Spine, 75, 634-642. http://dx.doi.org/10.1016/j.jbspin.2008.10.001

[7] Ouédraogo, D., Ouédraogo, T., Kaboré, F., Zan, A., Kafando, H., Nacoulma, E., Tieno, H. and Drabo, J. (2010) Quels sont les facteurs de risque associés à l’ONATF chez le sujet noir africain du Burkina Faso? www.rhumatologie.asso.fr

[8] Anie, K.A., Egunjobi, F.E. and Akinyanju, O.O. (2010) Psychosocial Impact of Sickle Cell Disorder: Perspectives from a Nigerian Setting. Global Health, 6, 2. http://dx.doi.org/10.1186/1744-8603-6-2

[9] Koo, K.-H., Kim, R., Kim, Y.-S., Ahn, I.-O., Cho, S.-H., Song, H.-R., Park, Y.-S., Kim, H. and Wang, G.-J. (2002) Risk Period for Developing Osteonecrosis of the Femoral Head in Patients on Steroid Treatment. Clinical Rheumatology, 21, 299-303. http://dx.doi.org/10.1007/s100670200078

[10] Wang, Y.S., Yin, L., Li, Y.B., Liu, P.L. and Cui, Q.J. (2008) Preventive Effects or Puerarin on Alcohol-Induced Osteonecrosis. Clinical Orthopaedics and Related Research, 466, 1059-1067. http://dx.doi.org/10.1007/s11999-008-0178-7

[11] Ngos, J.A. (2003) Complications de l'appareil locomoteur dans la drépanocytose homozygote à l'âge adulte à Yaoundé. Thèse de doctorat en médecine, Université de Yaoundé I, Yaoundé.

[12] Tchuisseu Ngankem, I.A., Ndumbe, P.M., Doualla, M.S. and Messomo P.A. (2007) Prévalence des manifestations rhumatologiques dans l'infection à VIH/SIDA au Cameroun. Sidanet, 4, 1015.

[13] Ficat, R.P. and Arlet, J. (1980) Ischemia and Necrosis of Bone. Williams and Wilkins, Baltimore, 171-182.

[14] Hamilton, T.W., Goodman, S.M. and Figgie, M. (2009) SAS Weekly Rounds: Avascular Necrosis. HSS Journal, 5, 99113. http://dx.doi.org/10.1007/s11420-009-9107-x

[15] Lafforgue, P. (2009) Ostéonécrose de la tête fémorale. Revue du Rhumatisme, 76, 166-172.

[16] Collet, P. (2005) Manifestations ostéoarticulaires des anémies. EMC Elsevier Masson SAS, Paris, Appareil Locomoteur.

[17] Akinyoola, A.L., Adediran, I.A., Asaleye, C.M. and Bolarinwa, A.R. (2009) Risk Factors for Osteonecrosis of the Femoral Head in Patients with Sickle Cell Disease. International Orthopaedics, 33, 923-926. http://dx.doi.org/10.1007/s00264-008-0584-1

[18] Oniankitan, O., Tagbor, K.C., Koffi-Tessio, V.E.S., Kakpovi, K. and Mijiyawa, M. (2009) Profil sémiologique de l’ONATF chez les sujets porteurs des hémoglobines AA et AS. La Tunisie médicale, 87, 776-777.

[19] Lafforgue, P. (2006) Pathophysiology and Natural History of Avascular Necrosis of Bone. Joint Bone Spine, 73, 500507.

[20] Chagnaud, C., Dehaut, F.-X. and Kousmenko-Deturmeny, A. (2009) Fractures de contrainte de la région de la hanche. Revue du Rhumatisme, 76, 180-187. http://dx.doi.org/10.1016/j.rhum.2008.09.011

[21] Yombi, J.C., Vandercam, B., Dunja, W., Dubuc, J.E., Vincent, A. and Docquier, P.L. (2009) Osteonecrosis of the Femoral Head in Patients with Type 1 Human Immunodeficiency Virus Infection: Clinical Analysis and Review. Clinical Rheumatology, 28, 815-823. http://dx.doi.org/10.1007/s10067-009-1156-5

[22] Mulliken, B.D., Renfrew, D.L., Brand, R.A. and Whitten, C.G. (1994) The Prevalence and Natural History of Early Osteonecrosis of the Femoral Head. Iowa Orthopaedic Journal, 14, 115-119.

[23] Uea-Areewongsa, P., Chaiamunuay, S., Narongroeknawin, P. and Asavatanabodee, P. (2009) Factors Associated with Osteonecrosis in Thai Lupus Patients. A Case Control Study. Journal of Clinical Rheumatology, 15, 345-349. http://dx.doi.org/10.1097/RHU.0b013e3181ba3423 
Scientific Research Publishing (SCIRP) is one of the largest Open Access journal publishers. It is currently publishing more than 200 open access, online, peer-reviewed journals covering a wide range of academic disciplines. SCIRP serves the worldwide academic communities and contributes to the progress and application of science with its publication.

Other selected journals from SCIRP are listed as below. Submit your manuscript to us via either submit@scirp.org or Online Submission Portal.
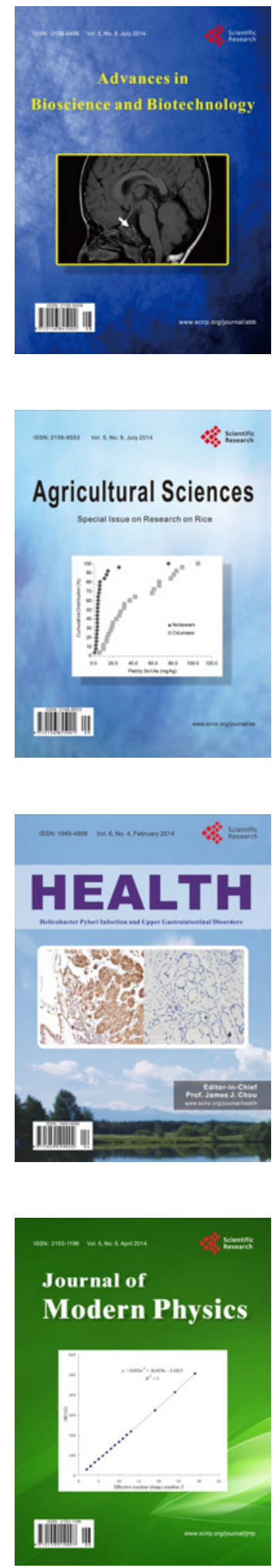
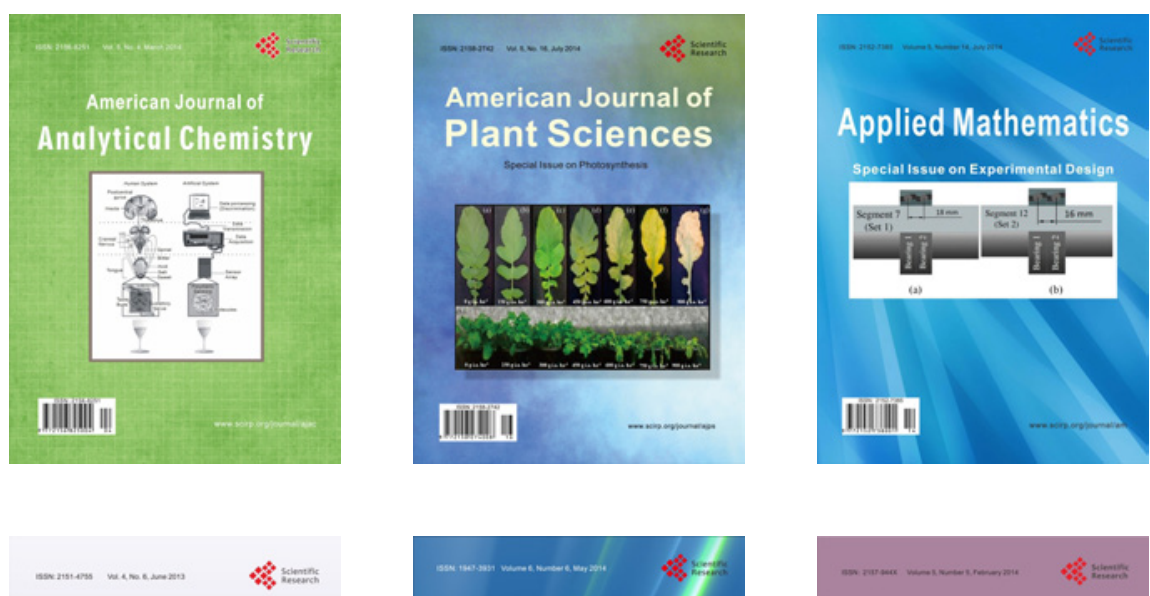

Creative Education
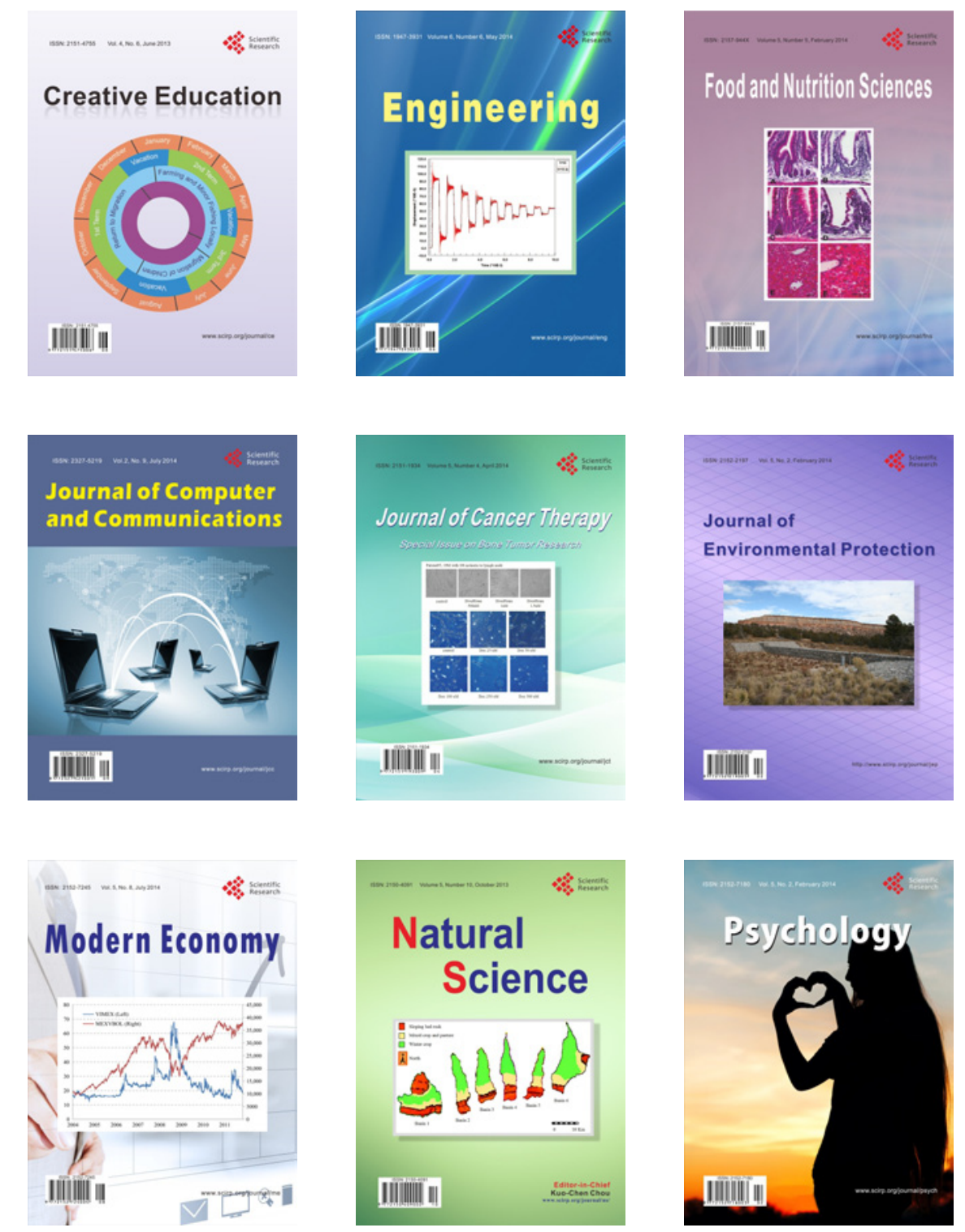